\title{
A KÖZIGAZGATÁS INFORMATIZÁLÁSÁTÓL A BEFOGADÓ E-KÖZIGAZGATÁSIG
}

A közigazgatás fejlesztése a közszolgáltatások múködésének színvonala, hatékonysága közvetlen és erôs hatással van a reálgazdaság teljesítményére, az információs társadalom, azaz a modern információs- és kommunikációs technológiai eszközök tényleges felhasználói számának kiterjesztésére. Ennek felismerése az e-közigazgatás témakörét az európai stratégiai törekvések, a társadalmi integráció, a befogadó információs társadalom programok középpontjába emelte. Hazánkban szintén kiváló lehetôségek adódnak a társadalom nyitottsága és néhány innovatív, a társadalmi modernizációt segítő lehetôség térnyerése révén.

Kulcsszavak: e-közigazgatás, e-befogadás, társadalmi integráció, IT-mentor

Napjainkban körülbelül 130 millió európai állampolgár használja az e-közigazgatási szolgáltatásokat, viszont közel 90 millió olyan felnőtt van, aki ugyan heti rendszerességgel használja az internetet, de az e-közszolgáltatásokat egyáltalán nem veszi igénybe. Hasonló arányszámok jellemzik Magyarországot is: a World Internet Project 2009-es adatai szerint a hazai internetezók 28,4 százaléka lépett kapcsolatba már valamilyen állami, önkormányzati hivatallal, a világháló segítségével, míg az internetezók több mint fele (52 százaléka) látogatta meg lakóhelyének webkikötôjét. Sajnos ettól jelentős mértékben elmarad az Ügyfélkapu használata, holott az elmúlt években ez volt a legfontosabb hazai e-közigazgatási fejlesztési projekt: az internetet használók mindössze 19 százaléka használta már személyesen az Ügyfélkaput valamilyen közigazgatással kapcsolatos ügy elintézésére (WIP, 2009).

Általános európai problémaként fogalmazódik meg, hogy az e-közigazgatási szolgáltatások számának növekedése és a nyújtott on-line szolgáltatások szintje nem kielégító, ugyanakkor a hirdetési kampányok sem járultak hozzá a kellő ütemú felhasználói szám növekedéséhez. Az alacsony használati mutatók ellenére a kutatók úgy látják, hogy magas azok aránya, akik a jövőben hajlandóak lennének használni az e-szolgáltatásokat, de ehhez leginkább az kell, hogy lehetôség nyíljon a kézzelfogható elônyök közvetlen megtapasztalásához.

Sajnos még napjainkban is - általánosságban - az tapasztalható, hogy az e-közigazgatási fejlesztések, beruházások megtervezése, végrehajtása pusztán önmagában informatikai feladatként fogalmazódik meg, annak társadalmi-gazdasági előfeltételeivel, hatásaival nem, vagy csak kevésbé foglalkoznak. Holott a közigazgatás, a közszolgáltatások múködésének színvonala, hatékonysága közvetlen és erős hatással van a reálgazdaság teljesítményére, az információs társadalom, azaz a modern információs és kommunikációs technológiai eszközök tényleges felhasználói számának kiterjesztésére. Görögországban egy új vállalat indításához 45 napra és 16 különböző hivatalos eljárásra van szükség, amelyeknek a költségei az egy fớre jutó jövedelem közel 70 százalékát teszik ki, míg ugyanehhez például Dániában - köszönhetóen ez e-közigazgatásnak mindössze 4 napra és 4 eljárásra van szükség, mindez pedig díjtalanul vehetố igénybe. Sajnos Magyarország sem áll jól ezen a téren, hiszen hazánkban még mindig egyötöddel magasabbak az adminisztrációs terhek az uniós átlagnál. A World Economic Forum 2009-es eredményei szerint - többek között ennek köszönhetően - Magyarország a 62. helyre csúszott vissza a három évvel ezelőtti 38-ról a vállalati versenyképesség terén.

Az e-közigazgatás fejlesztése évek óta az európai uniós stratégiai törekvések fókuszában szerepel, miközben napjainkban ezt a folyamatot szolgálja számos társadalomtudomány is (szociológia, közgazdaságtan, jogtudomány, vezetéstudomány, közigazgatástan stb.). Ezt az igen gyorsan változó jelenséget próbálja követni ennek e-közigazgatás-tudományi együttese (Budai, 2009). 
Az alábbi tanulmány azt a fejlődési ívet mutatja be, amely a közigazgatás hosszú évtizedes elektronizációjától - a napjainkban már a digitális kori kormányzást is felváltó - ,izokratikus kormányzáson” (Karvalics, 2008) - vagyis az egyenrangúságon és kölcsönösségen - alapuló új kormányzati modellig vonul végig: azaz a puszta informatikai fejlesztésektól a társadalmi-gazdasági hatás és hasznosság maximalizálásáig. Hipotézisünk szerint az e-közigazgatási fejlesztések kapcsán egyre inkább elótérbe kerülő társadalommodernizációs törekvések alapvető hatással lesznek a gazdasági válság utáni jövőben az állam és polgárai kapcsolatrendszerére.

\section{A hazai e-közigazgatás fejlesztésének három szakasza}

\section{A közigazgatás informatizálása}

Magyarországon mindössze 1996-ban kezdődött a központi államigazgatásban az IKT- (információs és kommunikációs technológia) eszközök adatainak gyújtése, így a korábbi idôszakból nincsenek összehasonlító adataink más országok közigazgatásával, azaz a magyar közigazgatás informatizálásának ütemét csak önmagához viszonyítva tudjuk vizsgálni (1. táblázat).

kétharmada, ugyanakkor az önkormányzatok esetében csupán egynegyede fért hozzá.

Messze nem mutattak ilyen biztató adatokat a lakossági e-közigazgatási használati mutatók ebben az időszakban, aminek persze számos oka van. A közigazgatás informatizálásának korszakában egyszerúen alig álltak rendelkezésre ügyféloldali e-szolgáltatások, másrészt a hazai internetezôk tábora is ijesztően alacsony volt. A TNS Hungary Government Online 2003-as adatai szerint hazánkban a 15 évesnél idősebbek mindössze 15 százaléka használt internetet, míg az e-kormányzati szolgáltatásokat csak 6 százaléka. Ezzel a vizsgált 32 ország között Magyarország az utolsók egyike volt. Az e-közigazgatási szolgáltatásokat ma jellemzően a középkorú, idôsebb és kisebb településeken élôk veszik igénybe, míg az e-közigazgatás első szakaszában inkább a 35 év alatti, nagyvárosokban élő fiatal felnőttek adták a fő bázist.

\section{Az e-közigazgatási alap-infrastruktúra kiépítése}

A közigazgatás informatizálásának hosszú korszaka 2003 körül zárult le, amit meglátásunk szerint egy 2006-ig tartó, az e-közigazgatás alap-infrastruktúrájának kiépítését célzó szakasz követett. Az előzô évek igen gyenge fejlődéséhez képest ebben az időszakban jelentős előrelépések és fontos fejlesztések

A közigazgatás számítógép-állománya kor szerinti bontásban, 2000-2004 között (db)

\begin{tabular}{|l|c|c|c|c|c|}
\hline & $\mathbf{2 0 0 0}$ & $\mathbf{2 0 0 1}$ & $\mathbf{2 0 0 2}$ & $\mathbf{2 0 0 3}$ & $\mathbf{2 0 0 4}$ \\
\hline 1 évnél fiatalabb & 23.674 & 23.379 & 29.540 & 28.611 & 37.003 \\
\hline 1-3 éves & 40.629 & 50.012 & 63.615 & 67.325 & 72.245 \\
\hline 3 évnél idősebb & 46.847 & 52.182 & 55.420 & 87.170 & 105.729 \\
\hline Összesen & 111.150 & 125.573 & 148.539 & 183.106 & 214.977 \\
\hline
\end{tabular}

Forrás: Nemzeti Hírközlési Hatóság, 2005

A magyar közigazgatás informatizálódási folyamatának érdekessége, hogy a fejlettebb országokkal szemben - ahol a vezető szerepet elsôsorban a szolgáltató, kereskedelmi szektor töltötte be, a digitális forradalom előnyeit először ốk használták ki - nálunk az államigazgatásban való felhasználás járt az élen.

Az ezredfordulót követôen újra fontos változást tapasztalunk, hiszen a közigazgatáson belül már az államigazgatásban látjuk a magasabb informatizálási szintet. 2003-2004-ben az államigazgatási intézmények döntô többségében megtalálható a számítógép, faxgép, mobiltelefon, az itt dolgozóknak több mint 80 százaléka használt számítógépet munkájához. Az intézmények döntő többsége rendelkezett interneteléréssel, kétharmada intranettel is. Az internethez a központi közigazgatásban dolgozók történtek, így megteremtődtek a múszaki, technológiai, infrastrukturális, eljárásrendi, szabványügyi, jogi alapok az e-közigazgatás széles körú bevezetéséhez, azaz egyben elkezdődhetett a legfontosabb ügyfél- és szolgáltatóoldali fejlesztések, alkalmazások, szolgáltatások elindítása is.

2003-2005 között sok kritikaérte azEU-tagállamokat az eEurope2005 célkitúzéseinek hiányos megvalósítása miatt, ám Magyarország esetében megállapítható, hogy ezeknek az elvárásoknak a rendelkezésre álló igen szúkös erôforrások és idôintervallum ellenére jól meg tudott felelni. Különösen igaz ez az infrastruktúra, az e-kormányzati közmú alapjainak lerakására, az unió e-közigazgatási rendszereihez való csatlakozásra, valamint a szükséges törvény- és rendeletalkotási folyamatra (2. táblázat). 
Különbözô on-line közszolgáltatást igénybevevók aránya 2003-2004-ben az EU országaiban

\begin{tabular}{|c|c|c|c|c|}
\hline & \multicolumn{2}{|c|}{ Vállalkozók } & \multicolumn{2}{|c|}{ Állampolgárok } \\
\hline & $\begin{array}{l}\text { 2003. év } \\
\text { EU-15 }\end{array}$ & $\begin{array}{l}2004 . \\
\text { EU-25 }\end{array}$ & $\begin{array}{l}\text { 2003. év } \\
\text { EU-15 }\end{array}$ & $\begin{array}{l}2004 . \\
\text { EU-25 }\end{array}$ \\
\hline Információt szerez & & & & \\
\hline $\begin{array}{r}\text { EU } \\
\text { Magyarország }\end{array}$ & $\begin{array}{l}44 \% \\
\text { n.a. }\end{array}$ & $\begin{array}{l}51 \% \\
44 \%\end{array}$ & $\begin{array}{c}21 \% \\
n . a\end{array}$ & $\begin{array}{l}45 \% \\
54 \%\end{array}$ \\
\hline Formanyomtatványokat tölt le & & & & \\
\hline $\begin{array}{r}\text { EU } \\
\text { Magyarország }\end{array}$ & $\begin{array}{l}38 \% \\
\text { n.a. }\end{array}$ & $\begin{array}{l}46 \% \\
41 \%\end{array}$ & $\begin{array}{l}10 \% \\
\text { n.a. }\end{array}$ & $\begin{array}{l}20 \% \\
25 \%\end{array}$ \\
\hline $\begin{array}{l}\text { Visszajuttat kitöltött } \\
\text { formanyomtatványokat }\end{array}$ & & & & \\
\hline $\begin{array}{r}\mathrm{EU} \\
\text { Magyarország }\end{array}$ & $\begin{array}{l}23 \% \\
\text { n.a. }\end{array}$ & $\begin{array}{l}36 \% \\
30 \%\end{array}$ & $\begin{array}{l}6 \% \\
\text { n.a. }\end{array}$ & $\begin{array}{l}12 \% \\
14 \%\end{array}$ \\
\hline
\end{tabular}

Forrás: Eurostat, 2005

Az Európai Unióban az e-közigazgatás 20 alapszolgáltatásának felkészültségi szintjét 2000 óta folyamatosan mérő Capgemini adatai szerint 2006-ban Magyarország lépett előre legnagyobbat az európai rangsorban, a 23.-ról a 14. helyre: 2003-ban a hazai elektronikus szolgáltatások csak 15 százalékos készültségi szintet értek el, ami 2006-ra felugrott 80 százalékra, míg a teljes mértékben on-line elérhető szolgáltatások aránya 50 százalékra, így mindkét mutatóban elértük az Európai Unió átlagát.

Mindez elsősorban a 2003-ban elfogadott e-kormányzat 2005 Stratégia és Programterv végrehajtásának köszönhetô, amely döntô mértékben az Európai Unió ajánlásában kijelölt alapvetô húsz közszolgáltatás elektronizációját, a megbízható múködést biztosító infrastruktúra, e-kormányzati közmú megteremtését célozta meg. Hiányosságként róható fel, hogy nem igazán történt elôrelépés az on-line közigazgatási szolgáltatások minôségének javításában, az állam átláthatóbb, hatékonyabb, költségtakarékosabb és ügyfélorientáltabb kialakításában, aminek hátterében elsősorban az elmaradt közigazgatási folyamatok reformját, ésszerúsítését látjuk. A gyakorlati lépések elsősorban a tevékenységek, egyes folyamatok elektronizálására fókuszáltak, míg a közigazgatási szervezetek és szintek közötti munkamegosztás, koordináció áttekintése, reformja sokkal kisebb hangsúlyt kapott. Az új, az e-Közigazgatás 2010 stratégia ennek megfelelôen már ez irányba is elmozdul egy professzionális keretrendszer kidolgozásával, miközben előtérbe kerül az ügyfélorientált megközelítés is.
A fejlett országok többségében azonosítható egyegy zászlóshajó projekt, fejlesztés az e-közigazgatás terén is. Az elmúlt évekre visszatekintve Magyarországon ilyennek tekinthetô az Ügyfélkapu kiépítése, valamint az e-adózás kötelezóvé tétele. Az elektronikus közigazgatáson belül eddig az e-adózás bizonyult az egyik legsikeresebb alkalmazásnak, nem utolsósorban azért, mert mind a vállalatok, mind az állam számára igen komoly idő- és pénzmegtakarítást tesz lehetővé. Nem véletlen, hogy rekordok születnek: az Egyesült Királyságban például 2008-ban 40 százalékkal több adózó küldte el az interneten keresztül az íveket, mint egy évvel korábban. A határidő lejárta előtti utolsó 24 órában 150 ezer bevallás érkezett be, azaz a rendszernek óránként 6000 , tehát másodpercenként két adóbevallást kellett befogadnia. Összevetésképpen: Magyarországon 345.000 bevallás volt a napi rekord, az óránkénti pedig 26.249 darab.

A magyar e-kormányzat egyik legnagyobb projektje az elektronikus adó- és járulékbevallás bevezetése, ami többéves elôkészület, fejlesztés és tesztelés után 2006ban érkezett kritikus fázisba, hiszen az év végéig Magyarország valamennyi munkáltatójának regisztrálnia kellett magát a rendszerben, és 2007. január 31-től kötelezôvé vált számukra az elektronikus rendszer használata az Ügyfélkapun keresztül (3. táblázat).

Szakértói becslések szerint 10-50 ezer forint közötti összegre tehetố az a megtakarítás, amit a formanyomtatványokon történő bevallás megszúnésével egy-egy cég elérhet, míg ez az államkincstár számára 300-400 millió forintos megtakarítást jelenthet. 
A regisztrált adózók számának és az általuk elektronikusan benyújtott bevallások számának alakulása az elmúlt öt évben

\begin{tabular}{|l|c|c|c|c|c|}
\hline & $\mathbf{2 0 0 2}$ & $\mathbf{2 0 0 3}$ & $\mathbf{2 0 0 4}$ & $\mathbf{2 0 0 5}$ & $\mathbf{2 0 0 6}$ \\
\hline Regisztrált adózók száma & 610 & 860 & 3.000 & 40.000 & 600.000 \\
\hline Elektronikusan benyújtott bevallás (db) & 8 ezer & 40 ezer & 150 ezer & 520 ezer & $\begin{array}{c}2800000 \\
\text { (becslés) }\end{array}$ \\
\hline
\end{tabular}

Forrás: APEH, Pillér Kft., 2006

A hazai e-közigazgatási alapok megteremtésének nagyon fontos állomása volt a jogi, szabályozási környezet biztosítása. A 2005-ös esztendóben számos olyan törvény született meg vagy lépett hatályba, amely döntő jelentőségú az elektronikus közigazgatásra való áttérés szempontjából.

Az e-ügyintézés effektív múködésének és az azt támogató törvényi háttér megteremtésének alapvetô fontosságú eleme a „2004. évi CXL. törvény a közigazgatási hatósági eljárás és szolgáltatás általános szabályairól", az úgynevezett Ket-törvény, amely egy közel 50 éves jogszabályt újított fel. A Ket. értelmében már nem az ügyfélnek kell a hivatalok között ingáznia különbözó adatokért, ha azok valahol már szerepelnek az állami/önkormányzati adatbázisokban, az ügyfelet nem kötelezhetik olyan adatok beszerzésére, amelyek a magyar hatóságok nyilvántartásában valahol már szerepelnek. Ha mindezt a közigazgatás papír alapon fogja végezni, akkor múködésképtelenné fog válni, hiszen már 2003-ban az önkormányzatoknál kezelt ügyiratok száma meghaladta a 27 milliót. Fontos szemléleti változás is kiolvasható a törvénykezésból, hiszen megfordult a szabályozási modell: most már az lesz a kivétel, ha valamit nem lehet elektronikusan is intézni.

A Ket. megjelenésének egyik fontos hatását az elektronikus aláírás elterjedésének felgyorsulásában várták a szakemberek. Úgy vélték, a hatósági eljárások interneten keresztüli intézését lehetővé tevő törvény minden bizonnyal megmozgatja majd e piacot, ám az elmúlt három év messze nem hozta meg ezeket az eredményeket. Az elektronikus aláírásról a felnőtt magyar lakosság harmada hallott már, azonban a szolgáltatást a megkérdezettek alig két százaléka használta, míg száz internetező közül mindössze 6 rendelkezik tapasztalatokkal az elektronikus aláírással kapcsolatban - derült ki a GKI 2005. évi monitoringvizsgálatából.

2006. január 1-jén lépett hatályba az elektronikus információszabadságról szóló törvény, amelynek célja, hogy meghatározza az állami, önkormányzati vagy jogszabályban meghatározott egyéb közfeladatokat el- látó szervek elektronikus formában milyen módon kötelesek a tevékenységükkel kapcsolatos legfontosabb adatokat rendszeresen közzétenni.

A 2006-ig tartó korszakról összegzésül elmondhatjuk, hogy az e-közigazgatás alap-infrastruktúrájának kiépítésével párhuzamosan megnövekedtek az állampolgári és vállalkozói igények a valóban szolgáltató jellegú, minőségi közigazgatással szemben. Mindezek ellenére 2006-ig hazánkban nem kötődött össze megfelelő hangsúllyal a közigazgatás reformja, illetve modernizációja az elektronikus közigazgatási szolgáltatások eszközeinek és lehetôségeinek hangsúlyozásával, tudatosításával, holott az említett célok eléréséhez minden fejlett országban segítségül hívták az IKT-eszközöket.

\section{Az e-közigazgatás társadalmasítása}

A 2007-tôl kezdődő legújabb szakasz azonban már teljesen új kihívásokat támaszt az e-közigazgatás elé, amit az e-közigazgatás társadalmasítási szakaszának neveztünk. Előtérbe kerülnek az ügyfélközpontú, magas szolgáltatási szintú, azaz a személyre szabható e-szolgáltatások, a versenyképes társadalom és gazdaság előmozdítása érdekében a hatékonyság és hatásosság elôsegítése, a web2.0 alkalmazásokban rejló lehetôségek kihasználása, valamint mindezek előmozdítása érdekében a szolgáltatóoldali folyamatok modernizációja. 2007-tól már mindenképpen a minőségi szolgáltatások - elsősorban a perszonalizáció és a felhasználó-központúság - irányába kell elmozdulni, hiszen itt tapasztalható a legnagyobb lemaradásunk az unió országainak átlagához képest.

Nem új keletú, ám a sikeres országok - az utóbbi 1-2 évben különösen Ausztria, Portugália, Szlovénia - visszatéró tapasztalata, hogy az e-közigazgatás fejlesztése nem lehet eredményes határozott és világos politikai szándék, kinyilvánított akarat nélkül. Legnagyobb hiány pontosan e területen tapasztalható Magyarországon. Az utóbbi években az e-közigazgatásnak - sem magának az információs társadalomnak - nincs emblematikus képviselóje a politikai vezetôk 
között. A prioritások folyamatosan elmosódnak, ezeket nem tudja senki egységes egészként kezelni, jó gazda módjára irányítani, aminek következtében egyre csak halmozódnak az el nem, vagy csak félig elvégzett feladatok. Folyamatosan elmaradnak a társadalmi tudatosítást, a használat elterjedését elősegítô akciók, programok, pedig az adatok azt mutatják, hogy az internet alacsony elterjedtségi mutatói ellenére az elektronikus közigazgatás nagyobb mértékú használata lehetne az a húzóágazat, amely az IKT-eszközök használata, esetleg az ezekbe való beruházás felé terelhetné a most még nem felhasználók népes táborát. A lakosság közel fele pozitívan viszonyul az elektronikus ügyintézéshez, továbbá az elektronikus kormányzati és önkormányzati szolgáltatások meglétével tisztában lévoók 40 százaléka tervezi, hogy a jövóben ki is próbálja a szolgáltatást.

A még mindig jellemzően fiatal, városi, gazdagabb rétegeket reprezentáló internetezókkel szemben az e-közigazgatás használói inkább középkorúak, idősek, és sokan élnek közülük kisebb városokban, községekben. Mindenképpen figyelemre méltó, hogy a felhasználókon belül a szélessávú háztartásokban élốk milyen kiemelkedő arányban használják az e-közigazgatás szolgáltatásait.

Elszomorító, hogy e kedvező tendenciákat Magyarország - az európai uniós politika határozott törekvései ellenére - sem használja ki a befogadó információs társadalom, a befogadó e-közigazgatás erôsítése érdekében.

A sok hiányosság ellenére legalább egy területen példamutató eredményeket érhettünk volna el. A magyarországi IT-mentor program sokáig egyedi kezdeményezés volt, ám mára ez a helyzeti előny is elszállt. Az IT-mentor szolgáltatás, szakma csíráit már a 2001ben elfogadásra kerülő Nemzeti Információs Társadalom Stratégiában is megtalálhatjuk, de a 2004. év elején megjelenố e-Kormányzat 2005 stratégiában már „IT-mentornak” neveztük azt a közvetító szakembert, akinek a részvétele nélkül elképzelhetetlen az elektronikus közszolgáltatások társadalmasítása. A Magyar Információs Társadalom Stratégia már külön programban foglalkozott a szakma kialakításával.

A magyar társadalom többsége sajnos még azokkal az alapvetô lehetőségekkel, előnyökkel sincs tisztában, amelyeket a modern információs és kommunikációs technológiai eszközök nyújthatnak számukra. Az ITmentor feladata, hogy társadalmi közvetítóként hozzásegítse a digitális írástudásban járatlanokat az IKTeszközök által nyújtott szolgáltatásokhoz, információs lehetőségekhez, forrásokhoz, tájékoztatást nyújtson az on-line világ lehetőségeirôl azok számára, akiknek nincs hozzáférésük, ismeretük vagy motivációjuk.

\section{Befogadó e-közigazgatás}

Az ITTK az Elektronikus kormányzati Központ felkérésére 2008. év végén kérdőíves vizsgálatot folytatott a teleházakban, könyvtárakban dolgozó IT-mentor, e-tanácsadó szakemberek körében. A kutatás eredményei szerint hazánkban a közösségi hozzáférési helyeken, például teleházakban, e-Magyarország pontokon, könyvtárakban tevékenykedő társadalmi közvetítók, IT-mentorok kiemelt szerepet játszanak az információs társadalom határainak kiszélesítésében, a segítettek életkorától és lakhelyének nagyságától függetlenül. Különösen igaznak tûnik ez az on-line közigazgatási szolgáltatások eljuttatásában a digitális írástudásban járatlan állampolgárokhoz, vállalkozásokhoz, így indokolt lenne ennek az új szakmának a további megerősítése.

Az utóbbi évek magyarországi kutatásai azt támasztották alá, hogy a társadalmi közvetítóknek kiemelt szerep jut a hazai információs társadalom fejlődésében. $\mathrm{Az}$ internetet nem használók körülbelül fele él olyan körülmények között, hogy otthonukban nemcsak a számítógép és az internet nem érhetố el, de nincs olyan családtagjuk sem, aki internetezik. Azaz a magyar társadalom jelentôs része nemcsak fizikai, infrastrukturális értelemben, de a társadalmi kapcsolatok tekintetében is kirekesztett az információs társadalomból. Ráadásul a nem használók szintén közel felét személyesen még soha senki nem akarta meggyőzni arról, hogy számukra az információs és kommunikációs eszközök számos lehetôséget, előnyt nyújthatnak.

Ennek következtében az utóbbi években a figyelem egyre sürgetốbb módon a társadalmi közvetítók irányába terelődött, azaz az olyan szakemberek felé, akik - leegyszerúsítve - képesek arra, hogy a hétköznapi ügyes-bajos dolgaink, problémáink egy részének megoldásában segítségül tudják hívni a hálózati társadalom, az elektronikus szolgáltatások és tartalmak világát.

Különösen az e-közigazgatási szolgáltatások elterjesztésében játszhatnak kiemelt szerepet a társadalmi közvetítók, több okból kifolyólag is. Egyrészt a közszolgáltatásokat igénybe vevoók több mint fele még mindig a közvetlen emberi kapcsolatot igényli a szolgáltatás igénybevételekor. Az eUSER kutatása ${ }^{1}$ megállapítja, hogy a kormányzati szolgáltatások igénybe vevói még mindig előnyben részesítik a személyes ügyintézést, habár jelentős különbségek vannak az egyes országok között (4. táblázat).

A kutatás eredményeire támaszkodva a 2007-es Liszszaboni Deklaráció már külön fel is hívja a figyelmet arra, hogy az e-közigazgatási szolgáltatások nyújtását kombinálni kell társadalmi közvetitók elérhetôségével, 
4. táblázat hogy körülbelül minden ötödik IT-mentor használja az

Az e-közigazgatás társadalmi közvetítői

\begin{tabular}{|l|c|c|}
\hline \multicolumn{1}{|c|}{$\begin{array}{c}\text { A kapcsolat } \\
\text { típusa }\end{array}$} & $\begin{array}{c}\text { Európai minta } \\
\text { átlaga }\end{array}$ & Magyar minta átlaga \\
\hline Személyes & 80,9 & 89,0 \\
\hline $\begin{array}{l}\text { Telefonos } \\
\text { kapcsolat }\end{array}$ & 42,4 & 36,5 \\
\hline Posta & 39,1 & 22,5 \\
\hline $\begin{array}{l}\text { Internet } \\
\text { vagy e-mail }\end{array}$ & 17,1 & 7,9 \\
\hline Fax & 5,1 & 3,6 \\
\hline SMS & 2,6 & 0,7 \\
\hline
\end{tabular}

Forrás: eUSER, 2006

akiket megfelelő képzésben kell részesíteni, és jogszabályban rögzített jogosítványokkal kell felruházni ahhoz, hogy más állampolgárok helyett eljárhassanak hivatalos ügyekben.

A hazai e-közigazgatási szolgáltatások elterjedésében meghatározó szerep hárul az IT-mentorokra, e-tanácsadókra. Az interneten keresztüli hivatalos ügyintézés során az internethasználók 65 százaléka kért már segítséget valamilyen társadalmi közvetítőtől (WIP, 2009).

A hazai - 34 kérdést tartalmazó on-line kérdőíves adatfelvételünk során összesen 234 - könyvtárakban, teleházakban, e-Magyarország pontokban, múvelődési házakban és civil szervezeteknél tevékenykedô - társadalmi közvetítőként tevékenykedő szakember nyújtott számunkra információkat.

Az IT-mentori munkának igen jelentôs részét teszi ki az e-közigazgatási szolgáltatások használata, hiszen a válaszadók 80 százaléka az IT-mentori munkája során kapcsolatba lépett interneten keresztül valamilyen közigazgatási szervvel az elmúlt 3 hónapban. Ez a mutatószám a magyar internetezó lakosság körében mindössze 22 százalék.

Nagyon figyelemre méltó, hogy az IT-mentorok nemcsak az általános használati mutatókban, hanem a magasabb szolgáltatási szintek elérésében is élen járnak. Az on-line módon felkeresett közigazgatási szervtól a válaszadók 82 százaléka töltött le formanyomtatványt, 46 százalékuk juttatott vissza itt kitöltött nyomtatványt.

A mentorok 98 százaléka ismeri az Ügyfélkaput, ezen belül majdnem minden negyedik szakember legalább heti rendszerességgel használja is azt az ügyfelek ügyeinek intézése céljából. A leggyakrabban használt szolgáltatások a hírek olvasása, az információk keresése, valamint linkek elérése. Az IT-mentorok 70 százaléka legalább havi rendszerességgel belép az Ügyfélkapun a személyes azonosítójával. Kiemelhetjük még,
Ügyfélkaput heti rendszerességgel arra, hogy ügyleírásokat keressen, olvasson. Ezzel szemben a virtuális okmányirodát heti rendszerességgel csak a mentorok 13 százaléka használja.

A felmérés szerint a mentorok egy hónap alatt átlagosan 10 embernek nyújtanak segítséget az e-közigazgatással kapcsolatos ügyek intézésében, ami az eUSER felmérés adataival szemben igen magas arányt mutat.

Az e-közigazgatás mellett a mentoroktól a számítógép és az internet használatával kapcsolatos tanácsokat is kértek a közösségi pontokra látogatók. Legnagyobb arányban a különböző kommunikációs alkalmazások (internetes telefon, chat, e-mail) használatában nyújtottak segítséget a mentorok. Több mint 80 százalékukhoz fordultak különböző információk megkeresésével, mint például oktatási és képzési lehetőségek, vagy egyes termékekkel kapcsolatos információk.

Az ügyfélkört alaposabban megvizsgálva kiderül, hogy a mentorok szerint a legkülönbözóbb életkori csoportokhoz tartozó emberek keresik fel óket, a középkorúak aránya $41 \%$, ami meghaladja a fiatal felnóttek $26 \%$ és a 60 éven felüliek $17 \%$ arányát.

$\mathrm{Az}$ életkor mellett fontos tényezóként jelenik meg a települések nagysága is. A kutatás érdekes eredménye, hogy a legtöbb kérdés esetében az apróbb településeken és a nagyobb városokban hasonló arányban keresik meg a mentorokat az adott problémákkal. Ez alól kivételt csupán a szociális ellátással kapcsolatos információk és az agrártémák jelentettek: a kistelepüléseken a szociális és a mezőgazdasági kérdések egyaránt lényegesen gyakrabban jelentek meg a mentori gyakorlatban.

A mentorok rendszeresen nyújtanak olyan területeken is tanácsokat, ahol speciális előképzettségekre lehet szükség. A kistelepüléseken található közösségi hozzáférési pontokat például gyakran keresik fel mezőgazdasági kérdések kapcsán. Ennek ellenére a mentorok többsége úgy érzi, elsősorban számítástechnikai ismeretei miatt tud hatékonyan segíteni a hozzáfordulóknak.

A kérdőívet kitöltô IT-mentorok 34 százaléka a mentori munkához szükséges tudásterületek közül a számítástechnikát emelte ki. Ha a mentorok elsősorban számítástechnikai szakemberek, akkor másodsorban fóleg pedagógusok, illetve szociális munkások.

A fentiekkel összhangban az IT-mentorok a munkavégzést jellemzô kijelentések közül legfontosabbnak az átfogó digitális kompetencia fejlesztését tartották. Hasonlóan fontosnak tartották, hogy munkájuk során segítsék elő, hogy a kliensek aktív részesei legyenek az információs társadalomnak. 


\section{Összegzés}

Magyarország viszonylag késő́n kezdte meg az e-közigazgatás alapjainak kiépítését, ám az eEurope programokhoz ${ }^{2}$ való csatlakozással ezt a hátrányunkat viszonylag gyorsan le tudtuk dolgozni. A 2003-2006 közötti időszakban az addigi igen gyenge fejlődéshez képest jelentős előrelépések és fontos fejlesztések történtek: kialakultak a fontosabb múszaki, technológiai, infrastrukturális, eljárásrendi, szabványügyi, jogi alapok az e-közigazgatás széles körú bevezetéséhez, ami már jó alapot jelentett a legfontosabb ügyfél és szolgáltatóoldali fejlesztések, alkalmazások, szolgáltatások elindítására is. Sajnos az e-közigazgatás ebben a szakaszban fóként az államigazgatás elektronizációját jelentette, míg az e-önkormányzatok fejlesztése megfelelően erős kéz koordinálása nélkül történt. A közigazgatás informatizálásának és az e-közigazgatás alapjainak lerakása döntô mértékben informatikai fejlesztések keretében történt, ám ezek a fejlesztések elsôsorban a múszaki szempontokat vették figyelembe, az elvárt gazdasági-társadalmi hatásokat nem.

Ebból következően a magyarországi e-közigazgatás fejlődésének legújabb szakaszában a további fejlesztéseknek már a szolgáltatások ügyfélközpontúságára, a mindenki által elérhetô, könnyebben, egyszerúbben használható szolgáltatások kialakítására, a befogadó e-közigazgatás megteremtésére kell fókuszálniuk. Az e-közigazgatás fejlesztése egy professzionális és politikailag kiemelt jelentőségú, de ugyanakkor komplex megoldásokat igénylő szakterületté vált, amiben már nem az informatikai, múszaki megoldásokon van a hangsúly, hanem ezen eszközök hosszabb távú gazdasági-társadalmi hatásainak maximalizálásán. Ennek értelmében az Európai Unió már nem általánosságban beszél az információs társadalom fejlesztéséról, hanem az IKT-eszközök segítségével elérhetô befogadó társadalom megközelítést preferálja. Az e-befogadáson belül az e-közigazgatási fejlesztéseknek pedig kiemelt szerepe van, amit a magyarországi e-közigazgatási szolgáltatások iránti igények, használati mutatók is alátámasztanak.

\section{Lábjegyzet}

${ }^{1}$ Lásd az eUser felmérés eredményeit, http://www.euser-eu.org/ Document.asp?MenuID=6

${ }^{2}$ Elsősorban a 2001 közepén meghirdetett eEurope+ Akció Tervhez.

\section{Felhasznált irodalom}

BME-UNESCO Információs Társadalom- és Trendkutató Központ (2008): Elektronikus közigazgatás, éves jelentés, 2008. Innen: Piac és Profit, november

Budai B. (2009): Az e-közigazgatás elmélete - axiomatikus megközelítésben. Információs Társadalom 2009/2. 68-79. old.

Capgemini (2007): The User Challenge Benchmarking The Supply of Online Public Services. 7th Measurement

Dombi G. - Kollányi B. - Molnár Sz. (2007): Társadalmi befogadást most! Az életminőség, digitális esélyegyenlőség és a társadalmi megújulás Magyarországa. eInclusion éves jelentés. Innen: http://einclusion.hu/

Dombi G. - Kollányi B. - Molnár Sz. (szerk., 2008): e-Befogadás Magyarországon. Éves Jelentés, 2008. Fókuszban: az idősödốk befogadásának problematikája. Innen: http://einclusion.hu/

European Commission (2008): Preparing Europe's digital future. i2010 Mid-Term Review. Brussels, 17.4.2008 SEC(2008). COM(2008) 199 final

Gáspár M. (2008): Képességet mindenkinek! Információs társadalmi mentorok a digitális szolidaritás szolgálatában. Százhalombatta város Önkormányzata, Teleház Szövetségek Európai Uniója i2010 eGovernment Action Plan: http://europa.eu/scadplus/leg/en/lvb/124226j.htm

Kollányi Bence - Molnár Szilárd (2008): A társadalmi közvetítók szerepe a befogadó e-közigazgatás fejlesztésében. Kézirat

Miniszterelnöki Hivatal (2007): e-Közigazgatás 2010 Stratégia. Innen: http://ekk.gov.hu/hu/ekk/strategia

NemzetiHírközlési Hatóság (NHH)hírközléspiaci gyorsjelentései. Innen: http://www.nhh.hu/?id=menu\&mid=1052

World Internet Project: nemzetközi http://www. worldinternetproject.net/, magyarországi: http://www. tarki.hu/research/wip/ismerteto.html

Z. Karvalics L. (2008): Úton a digitális kori kormányzás felé. Demos, Budapest 